method of inorganic group analysis, and separations of the metals by adsorption and partition-type chromatography were described by several authors. The mechanism of inorganic chromatography on alumina was discussed by L. Sacconi, who concluded that this adsorption is due mainly to the preferential adsorption by alumina of aquo-ions. Filter paper impregnated with alumina has also been used to separate the metals; but the method does not seem to be so efficient as paper partition chromatography. Using the latter technique, metals have been separated on columns of cellulose and sheets of filter paper in the usual manner, using one- and two-dimensional chromatography. Perhaps the most remarkable example of the use of synthetic resins for the separation of the metals was the communication of F. H. Spedding on the separation of the rare-earth salts. This separation was necessitated because of the formation of the rare earths as fission fragments of the heavy elements. The separation is achieved by adsorption followed by elution from columns of resinous ion exchange material, such as 'Amberlite $I R 100^{\prime}$; thus, elements hitherto requiring some twenty thousand operations for their preparation in the pure state and in relatively small yields become readily available in comparatively large amounts. A massive ingot of lanthanum and ingots of several other rare-earth metals were exhibited. The description of this remarkable achievement in inorganic chemistry concluded the papers on this aspect of chromatography. Various papers on the separation of organic materials formed the final part of the discussion.

The chromatographic separations of organic gases, liquids and solids were discussed in detail. The word 'chromatographic' is perhaps a misnomer in the majority of these separations, since the substances separated were identified by fluorescence, refractive index, optical rotation, colour reaction, or by some physical constant; rarely were the compounds themselves coloured. The majority of the separations were effected by partition chromatography, a few by adsorption, usually on alumina, and only one separation utilized adsorption on ion exchange columns. This was the large-scale separation of amino-acids from protein hydrolysates, which in a fow cases lead to the isolation of pure amino-acids. A very interesting account of the separation and isolation of vitamin $\mathbf{B}_{12}$ was given, which involved adsorption and partition chromatography on a variety of materials, and served to illustrate the importance of these new techniques in the field of biochemistry. Papers were given on the separation and determina. tion of black oils (fuel oils), petroleum, hydrocarbons, vapours and gases, carboxylic acids, steroids, proteins and carbohydrates. The separation of the amino-acids attracted the most attention. The conditions necessary for the quantitative separation of these substances have not yet been completely determined, since losses occur as the amino-acids travel down the paper. It is of interest to note, however, that these losses are negligible in the separation of the carbohydrates, and their determination is thus simplified.

At the conclusion of these pleasantly informal discussions, a summary was made by A. J. P. Martin, who suggested many ingenious applications of chromatography. Many other interesting observations and remarks were made, but the exigencies of space prevent their publication. The papers presented at the discussion are to be published in full by the Faraday Society.

\section{GEOPHYSICAL SURVEYS AND THEIR UTILIZATION 4 Hै:}

$\mathrm{A}^{\mathrm{T}}$

T the Newcastleymeeting of the British Association, a discussion on geophysics was held by Section A (Aathomatics and Physics), under the chairmanshif 4 Sir Sdrold Spencer Jones. Mr. B. C. Browne openel discussion with an account of

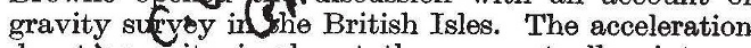
due thgravity is almost the same at all points on the surilice of the earth, but accurate measurements show that the value at the equator is about a half per cent less than at the poles. The normal value at any particular latitude is usually assumed to be that given by the international gravity formula. In the British Isles, the mean variation is approximately 1.3 milligals $\left(1.3 \times 10^{-3} \mathrm{~cm} . / \mathrm{sec} .^{2}\right)$ per mile. Superimposed on this are local variations arising from changes in height and the attraction of topographic features such as mountains and seas. After allowing for the effect of elevation and topography, the difference between the observed value of gravity and the value given by the international gravity formula is known as the Bouguer anomaly. This represents the attraction of the anomalous masses present within the earth.

The Bouguer anomalies are often of great assistance in the interpretation of geological structure, and gravimeter surveys are therefore frequently made when prospecting. During and since the Second World War, the Anglo-American and the AngloIranian Oil Companies have made several thousands of gravimeter measurements in England. These have been supplemented by additional observations made by the Department of Geodesy and Geophysics at the University of Cambridge, and the Geological Survey and the Imperial College of Science and Technology, London, are also taking up this work.

Thanks to the generosity of the oil companies in making their results available, it is now possible to obtain a fairly accurate picture of the trend of the Bouguer anomalies over most of the Midlands and southern England. In general, the agreement with the known geology is good. Positive anomalies occur in the west over the outcrops of the older Palæozoic rocks, while to the south-east they become more negative as the thickness of the Mesozoic cover increases. The Cheshire basin, where several thousands of feet of Trias occur, is associated with a gravity trough some 15 milligals deep. The Hampshire basin also shows up well, and an even more striking area of negative anomalies is found east of the Malvern Hills. The structure here is not yet known, but it is likely that many thousands of feet of carboniferous rocks may underlie this region. In other areas, however, results are anomalous. In Dartmoor and parts of Cormwall, unexpectedly low gravity values are found over igneous intrusions. A careful investigation of the gravity field and the distribution of rock densities would be of great interest and would probably throw much light on the geological structure of this complex region.

Besides the investigation of special areas, gravity measurements are of importance for more general geophysical studies and for geodetic calculations. It is therefore most desirable that results should be made generally available and the surveys extended to cover the whole country. The geodesy subcommittee of the National Committee for Geodesy and Geophysics has appointed a special sub-committee to 
consider this matter. Large areas, particularly in Scotland, Wales, northern and western England, still remain to be surveyed. This might very appropriately be done by university research departments, for not only would the results be of local geological interest, but also the work provides good training for students intending to take up geophysics as a career. Such a scheme would enable a general survey of the British Isles to be completed comparatively quickly. The results would be of great scientific value and might well lead to discoveries of considerable economic importance.

The next speaker, Mr. L. H. Tarrant, described recent geophysical surveys for oil in southern England. Since 1945, the Anglo-Iranian Oil Co. has carried out magnetic and gravity surveys over some 6,000 square miles between Birmingham, Bath, Hertford and Dover. Palæozoic outcrops of the Mendip, Malvern and Lickey Hills show up as positive ridges, while the coalfield basins of Somerset and east Kent appear as gravity 'lows'. There is a regional trend over the whole area, but when this is removed, the general directions of the linear gravity features can clearly be seen. These change from an east-west direction in the south and east to northsouth in the west. The more positive features may well be associated with anticline structures in the Palæozoic which might prove to be oil traps if Upper Carboniferous measures were present.

The whole area is covered with Mesozoic sediments, and the effect of these must be removed before attempting to interpret the structure of the Palæozoic basement. As a first step, the variation of anomaly with thickness of Mesozoic cover is obtained from bore-hole data in those regions where the Upper Carboniferous is absent. This shows that, on the average, $100 \mathrm{ft}$. of cover reduces the anomaly by 0.36 milligal, while other factors such as variations in the basement produce a standard deviation of \pm 3.8 milligals. The accuracy can be improved by dividing the Mesozoic strata into two groups, separated by the base of the Wealden. For the upper group, a reduction of 0.60 milligal $/ 100 \mathrm{ft}$. is found, while for the lower strata the corresponding figure is 0.31 milligal $/ 100 \mathrm{ft}$. These values do not agree. with those calculated from the observed differences in density. These are 0.88 and 0.50 milligal $/ 100 \mathrm{ft}$., respectively, corresponding to density deficiencies of 0.7 and $0.4 \mathrm{gm} . / \mathrm{cm}^{3}$. Some form of isostatic compensation is suggested as a possible explanation.

Having allowed for the effect of the Mesozoic cover, the form of the anomaly contours is considerably altered. The negative region to the south is replaced by some quite high areas, particularly near Kingsclere and Guildford. The trough between Worcester and Swindon persists, though it is less deep, and a marked basin appears between Oxford and Reading. To interpret these, the results of the survey of the Kent coalfield can be used. Here, allowing for the regional fall in gravity to the east-south-east, it is found that $500 \mathrm{ft}$. of Upper Carboniferous measures reduces the anomaly by 1 milligal. The probability of finding at least 1,000 feet of Upper Carboniferous can now be assessed. Where the residual anomaly is $-2 \cdot 0$ milligals, the chances are even. Since the standard deviation is \pm 3.8 milligals, the odds are 10 to 1 on where the anomaly is -8.0 milligals. Some 25 per cent of the area surveyed falls into this category, indicating considerable thickness of Upper Carboniferous. The potentialities of these regions both for coal and oil production are undoubtedly worth further investigation.

The final speaker, Prof. J. Satterly, spoke on geophysical research in Canada. The great mineral resources of that country provide abundant scope for geophysical prospecting, and at present there is a great demand for young geophysicists. Gravity observations have been made for more than fifty years by the Dominion Observatory at Ottawa, and recently a transcontinental traverse has been carried out with a gravimeter from Halifax to Vancouver. There are also several independent surveys of special areas, particularly in Alberta, where considerable oilfields have been found.

In Canada, the areas to be explored are so vast that special methods have to be employed. Airborne magnetometers have been used extensively, and aerial photography is playing an increasingly important part in both topographical and geological survey. Radioactive methods are being applied to a number of problems, especially for locating deposits of uranium. Much of the country consists of PreCambrian rocks, where the absence of fossils makes radioactive age determinations of special importance. A new mass spectrograph is being set up in Toronto for this work, and problems of heat flow in the earth are also receiving considerable attention. Seismology is actively pursued, and recently the small earthquakes or 'rockbursts' caused by mining operations have been used to establish accurate time-distance curves at ranges up to several hundreds of kilometres.

At present, there is keen interest in polar research, which is not unrelated to the fact that the Arctic lies directly between the United States and the U.S.S.R. A chain of fifty radar stations has been set up across the north of Canada, and expeditions to the far north have obtained much valuable information concerning conditions both on land and in the air. Magnetic measurements show that the north magnetic pole wanders about in an erratic manner, which fits in well with Bullard's theory of secular variations. Recently, these ideas have been greatly extended to explain the origin of the main field of the earth as due to the dynamo action of convection currents in the core of the earth. Canada has an up-to-date meteorological service, and oceanography is studied on both the Atlantic and Pacific coasts. In fact, there is scarcely a branch of geophysics which is not being actively investigated. The potential resources of Canada are enormous, and there are great possibilities both for research and development.

B. C. Browne

\section{OBITUARY}

\section{Prof. O. F. Curtis}

Througr the sudden and unexpected death on July 4, 1949. of Prof. Otis Freeman Curtis, the subject of botany and plant physiology has suffered the loss of one of its most earnest and devoted scholars His loss will be keenly felt in the United States where, at Cormell University and in the botghical and horticultural community at large, Dr. Curtis had long held a prominent and respected position. Plant physiologists everywhere will regret Dr. Curtis's sudden passing while still at the height of his powers and when it might have been expected that he would have had many years of active work ahead. 